\title{
PICTO TEXTUAL GLOSSES IN TEACHING VOCABULARY
}

\author{
Anita Fitria Nurwulan' ${ }^{1}$, Sobari $^{2}$ \\ ${ }^{1}$ IKIP Siliwangi \\ ${ }^{2}$ IKIP Siliwangi \\ ${ }^{1}$ Anitafitrianurwula.afn@gmail.com, ${ }^{2}$ www.bainr.gmail.com
}

\begin{abstract}
The purpose of this research is to know english vocabulary mastery incresed by using picto textual glossesin every meeting in class. The object of this research is 8 th grade students in Mutiara 1 junior high school. the main focus in teaching english is to improving students english vocabulary mastery . By improving vocabulary mastery, students will be improving english material easier. The data in this research come from interaction between teacher and students in learning process and it is as students learning activity in the class. the research instruments used test questions.The method of data collecting of the resarch is by using pretest-treatment-postest in the class. Based on pre test and post test, they showed some improvement on process of get new vocabulary from learning with that method. . The result or the conclusion can be got from the resarch by using picto textual glosses method, data from pre test and post test showed that there were some benefits of picto textual glosses method: 1 . Develop of students' memory ability to increasing vocabulary, 2 . Having a fun learning situation. The data showed $\mathrm{HI}$ is accepted, because Asymp. Sig. (2-tailed) worth 0,000. because the value of 0,000 is smaller; of, $<0.05$.
\end{abstract}

Keywords: Vocabulary, Vocabulary Mastery, Picto Textual Glosses

\section{INTRODUCTION}

Learning language covers some aspects. Basic aim of language learning nowdays is communication and vocabulary plays an important role in conversation (Komorowska, 2005) as cited in Nurdiansyah, Asyid, \& Parmawati (2019). One of the important aspects is linguistic aspect which covers grammar, vocabulary, pronunciation, structure, and so on. Beside those aspects, the learners also need to master the skills of the language such as listening, writing, reading, and speaking. However, it should be kept in mind that those skills cannot be learned discretely. Students who are learning English should master vocabulary skills integratedly. In other words, it is hard to master foreign language without mastering certain number of vocabulary (Farida, Isrina \& Apsari, 2019).

However, Vocabulary in English became a major factor difficulties of students. These difficulties make the lack of motivation to learn English for the students. While english vocabulary is a basic thing in English learning. Sometimes it is difficult to teach and improve students vocabulary. Especially on a diversity of students, who only met the English language in school lessons only. Brown (2001) views vocabulary items as a boring list of words that must be defined and memorized by the students, lexical forms are seen in their central role in contextualized, meaningful language. As brown said, the author found the problem of the students memorizing, especially to memorized english vocabulary and its meaning. Memorizing is the main factor to improve students english vocabulary. So, the author try to apply Picto Textual Method to stimulate students motivation of vocabulary memorizing.

\section{Teaching Vocabulary}


Teaching English vocabulary is a basic thing that must be done by a teacher, because a vocabulary is a pillar or basis for achieving other English knowledge. Vocabulary teaching is one of the most important components at many language classes. The main problem in teaching and learning vocabulary is a technique in teaching vocabulary that less of varation (Ibrohim, Septianti and Sadikin, 2018). In this case, the main problem in teaching vocabularies is the technique or method used by the teacher in delivering or teaching vocabularies.In teaching English vocabulary, the teacher must have the skills so that students are able to receive what is delivered. In teaching vocabularies, the teacher must pay attention to the level of focus of the student, because teaching vocabularies is the same as teaching memory ability.

\section{Vocabulary}

Learning a new language cannot be separated from vocabulary. Meaning which in learning a new language people have to know its vocabulary. Vocabulary can be defined in various ways. Experts have proposed some terms about vocabulary. According to Renandya and Richards (2002), vocabulary is a core component of language proficiency and provides much of the basis for how learners speak, listen, read and write. Without an extensive vocabulary and strategies for acquiring new vocabulary, learners often achieve their potential and may be discouraged from making use of language learning opportunities around them such as listening to the radio, listening to the native speaker.

Learning vocabulary is closely related with learning about words. Language users build a sentence by combining words for their communication to other people. According to Hatch and Brown (1995), vocabulary is a list or set of words for a particular language or a list or set of word that individual speakers of language might use. Meanwhile, according to Suyanto (2008) in his book entitled English For Young Learners, it is suggested that vocabulary is a collection of words that are owned by a language and give meaning if we use the language. Teaching vocabulary, the teacher have to teach the meaning of the word also.

\section{Picto textual glosses}

Picto Textual Glosses is one of another method that use multimedia. This method is to make student easy remember vocabulary and the meaning. It is also will make students motivated to learn english. This method almost same with learning use picture and picture. Arsyad (2013, p. 89)Visual-based Media (image or imagery) plays a very important role in the learning process. Visual Media can facilitate understanding (e.g. through elaboration of structures and organizations) and strengthening memory. Using images in multimedia will stimulate students to be more interested in the material presented.

\section{METHOD}

This research is the effectiveness picto textual glosses of teaching vocabulary. The purpose of the study is to improve student vocabulary comprehension and student interest to learn english by the another method used as picto textual glosses. This research uses quantitative research or and experiment researach with true experiment design. Research experiments in which the study was given a special treatment of a sample of research (Sugiyono, 2011, p. 72). The experimental Model used is Pretest-Posttest Control Group Design.

The subject of this study are the students of class junior high school in Bandung in the academic year of 2018/2019 consisting of 35 students. The data is collected with the pretest and posttest as an instrument. 
The way to do this research is first, give a pre test. The pre test is the form of a question about vocabulary, the initial pre-test is carried out without being given treatment first, to see how much students are able to remember vocabulary. After giving the pre test and knowing the results, a post test was carried out but, before the post test, the treatment was carried out before, the treatment was in the form of understanding material to remember vocabularies by using multimedia picture called picto textual glosses. The post test was the same questions as the pre test.

\section{RESULTS AND DISCUSSION}

\section{Results}

In this section the researcher using SPSS version 16.0 to answer whether picto textual glosses is effective to improve students' vocabulary at MUTIARA 1junior high school,with the title below:

Table 1. The Result of Pretest and Posttest

\begin{tabular}{|c|c|c|c|}
\hline No & Name & Pretest & Postest \\
\hline 1 & Student 1 & 60 & 85 \\
\hline 2 & Student 2 & 60 & 85 \\
\hline 3 & Student 3 & 45 & 70 \\
\hline 4 & Student 4 & 47 & 70 \\
\hline 5 & Student 5 & 55 & 70 \\
\hline 6 & Student 6 & 55 & 70 \\
\hline 7 & Student 7 & 55 & 70 \\
\hline 8 & Student 8 & 38 & 70 \\
\hline 9 & Student 9 & 50 & 70 \\
\hline 10 & Student 10 & 38 & 75 \\
\hline 11 & Student 11 & 38 & 75 \\
\hline 12 & Student 12 & 32 & 70 \\
\hline 13 & Student 13 & 40 & 70 \\
\hline 14 & Student 14 & 40 & 65 \\
\hline 15 & Student 15 & 40 & 65 \\
\hline 16 & Student 16 & 38 & 80 \\
\hline 17 & Student 17 & 38 & 80 \\
\hline 18 & Student 18 & 36 & 80 \\
\hline 19 & Student 19 & 38 & 80 \\
\hline 20 & Student 20 & 38 & 80 \\
\hline 21 & Student 21 & 45 & 75 \\
\hline 22 & Student 22 & 45 & 75 \\
\hline 23 & Student 23 & 44 & 75 \\
\hline 24 & Student 24 & 50 & 73 \\
\hline 25 & Student 25 & 50 & 73 \\
\hline 26 & Student 26 & 50 & 73 \\
\hline
\end{tabular}




\begin{tabular}{llll}
\hline $\mathbf{2 7}$ & Student 27 & 50 & 73 \\
\hline $\mathbf{2 8}$ & Student 28 & 52 & 73 \\
\hline $\mathbf{2 9}$ & Student 29 & 60 & 80 \\
\hline $\mathbf{3 0}$ & Student 30 & 60 & 80
\end{tabular}

The average value of students at pretest is 46.23 , while the average value of students in the posttest after being given treatment is 74.33 . There is a comparison and increase in the average value of students at the pretest and posttest values. The difference from the average value of the pretest and posttest is 28.1. There are 5 students who get a significant increase in value, while there are 3 students who get a low increase in grades. And there are 22 students who get a good increase in value.

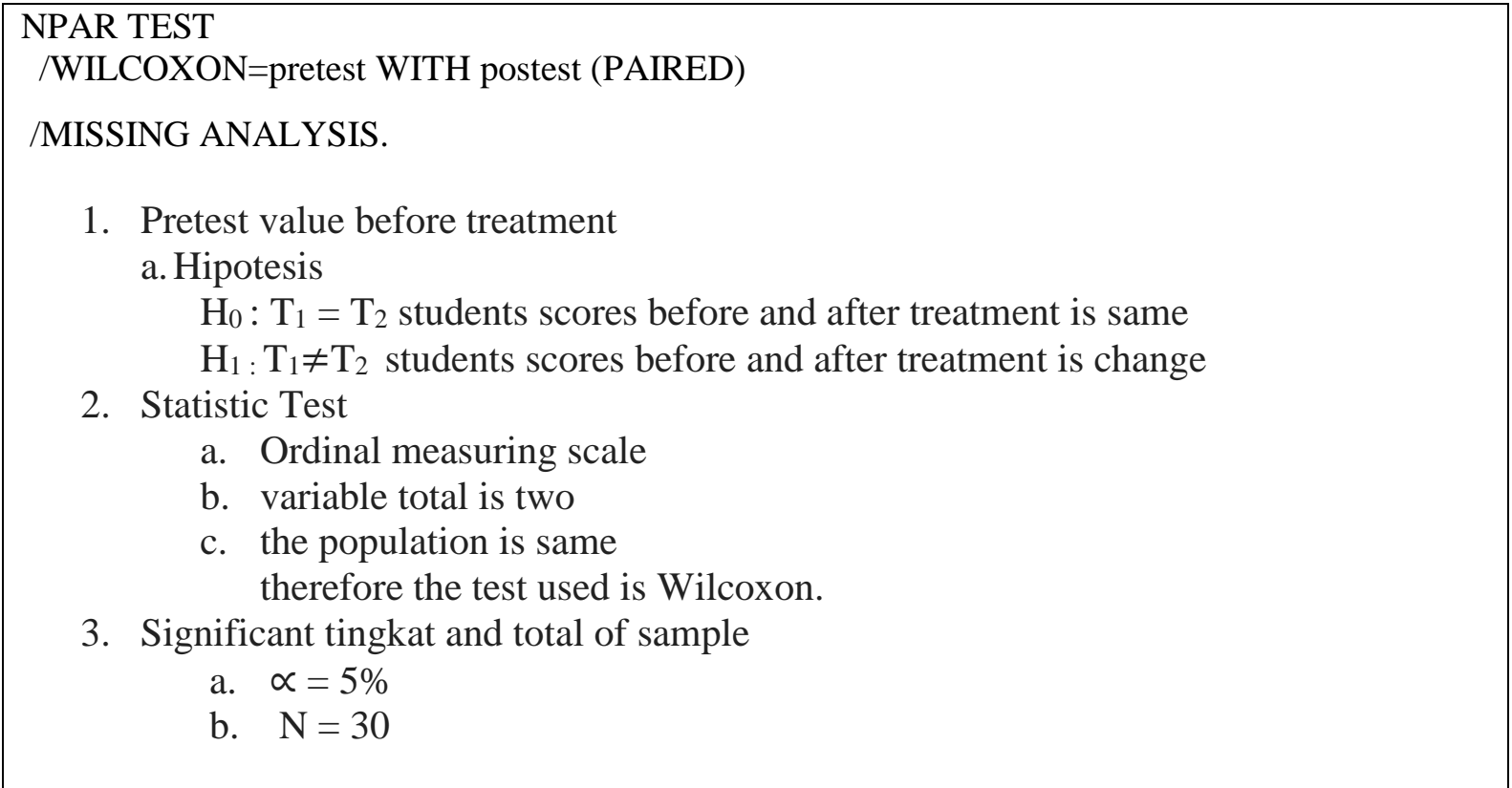

Before doing the analysis the first time is to identify the method to be used. First the author see from the purpose of comparing two populations, namely before and after being given treatment. meaning we want to see the difference in populations in pairs because it uses before and after with the same sample. From one we can use paired t test or Wilcoxon test.

The Sign-Wilcoxon test is a test to determine whether there is a difference between two dependent or paired samples and is used as an alternative to the Paired Sample T Test if the data are not normally distributed. Wilcoxon signed rank test is non-parametric which is related to ranking data or qualitative data (nominal or ordinal scale) or quantitative data that are not normally distributed. 
Table 2.Rank

\begin{tabular}{|rl|r|r|r|}
\hline & \multicolumn{1}{|c|}{ Ranks } \\
\hline postest - pretest & N & Mean Rank & Sum of Ranks \\
& Pogative Ranks & $0^{\mathrm{a}}$ & .00 & .00 \\
& Positive Ranks & $30^{\mathrm{b}}$ & 15.50 & 465.00 \\
& Ties & $0^{\mathrm{c}}$ & & \\
Total & 30 & & \\
\hline
\end{tabular}
a. postest $<$ pretest
b. postest > pretest
c. postest $=$ pretest

Negative rank or difference (negative) between the results of vocabulary learning for the pre test and post test is 0 , both at the N, Mean rank, and Sum Rank. This value of 0 indicates no reductionfrom the value of the post test to the value of the post test. Meanwhile positive rank or positive difference between vocabulary learning outcomes for pre test and post test. There are 30 positive data $(\mathrm{N})$, which means that 30 students have increased vocabulary learning outcomes from the post test value to the pre test value. The mean rank or average increase is 15.50, while the number of positive ranks or Sum of rank is 465.00.and the last is Ties. Ties is the similarity of the value of the post test and pre test, in the data entered, the value of ties is 0 . So it can be said there is no same value in the value of the post test to the pre test

Table 3. Test Statistic

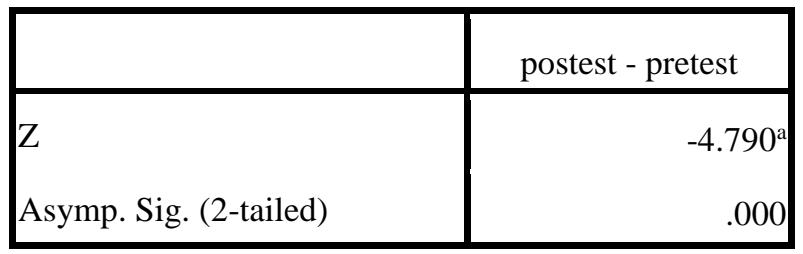

a. Based on negative ranks.

b. Wilcoxon Signed Ranks Test

\section{Criteria:}

If sig $>0.05 \mathrm{H} 0$ is accepted

If Sig. $<0.05 \mathrm{H} 0$ is rejected

$\mathrm{H} 0$ is rejected, If F value $>\mathrm{F}$ table or Pvalue $\leq \propto$

Pvalue $=0.000 \leq \propto=0.05=\mathrm{H} 0$ is rejected

Based on the "Test Statistics" output above, it is known Asymp. Sig. (2-tailed) worth 0,000. because the value of 0,000 is smaller; of, $<0.05$, it can be concluded that "Ha is accepted". It means that there is a difference between vocabulary learning outcomes for pre-test and posttest, so it can be concluded also that "there is an increase and influence of the use of group 
learning methods on vocabulary learning outcomes for junior high school students in class 8B" Therefore students scores before and after treatment is change. And it has improvement from pretest to posttest

\section{Discussion}

The discussion of this research is there are changes and differences from the post without treatment and pretest after treatment. actually increasing the students' vocabulary abilities through picto textual glosses can be done on grade 8 students.

\section{CONCLUSION}

The purpose of this study is to find out the effectiveness picto textual glosses to improve students vocabulary using quantitative methods. Based on the statistics of the data above, the results of the study show that the students vocabulary increase, it can be seen from the prestest and pretest scores and it can be seen from the result of statistics. The data from pre test and post test showed that there were some benefits of picto textual glosses method: 1. Develop of students' memory ability to increasing vocabulary, 3 . Having a fun learning situation. The data showedHI is accepted, because Asymp. Sig. (2-tailed) worth 0,000. because the value of 0,000 is smaller; of, <0.05, from the data there are 5 students who get a significant increase in value, while there are 3 students who get a low increase in grades. And there are 22 students who get a good increase in value. The result or the conclusion can be got from the resarch by using picto textual glosses method, students more attracted and they have spirit more to learn english. Especially in english vocabulary mastery, they can remember a lot of vocabulary and applied it into the material. And the researcher hope this paper could be seen as reflection of the skill in teaching vocabulary.

\section{ACKNOWLEDGMENTS}

How thankful I'am to be able to finish this paper. In this paper I would like to express my gratefullness who people helped, guided, and supported me in writing and finishing this paper. Thanks to my family especially my mother, my father and my husband who always give me financial, supporting in every way. Thanks to my supervisor, Mr.Trisnendri Syarizal, S.Pd, M.Hum, who was advised and revised as so detail to corrected my paper. And the last thanks to my classmate who always supported each other especially to Mr.Fahmi who always give information as detail as possible.

\section{REFERENCES}

Arsyad, A. (2013) Media Pembelajaran. Jakarta: Pt Rajagrafindo Persada.

Brown, H. D. (2001) Teaching By Principle. New York: Longman.

Farida, D., Isrina, H. D., \& Apsari, Y. (2019). The Implementation Of Flash Cards To Improve Students'vocabulary Mastery. Project (Professional Journal Of English Education), 2(3), 352-357.

Hatch, E. And Brown, C. (1995) Vocabulary,Semantic And Language Education. Cambridge: Cambridge University Press.

Ibrohim, A. T., Septianti, A. And Sadikin, I. S. (2018) 'Students 'Perception Toward Teaching 
English Vocabulary Through Total Physical Response ( Tpr ) Method', 1(2), Pp. 145156.

Nurdiansyah, D. M. R., Asyid, S. A., \& Parmawati, A. (2019). Using Color Coding To Improve Students'english Vocabulary Ability. Project (Professional Journal Of English Education), 2(3), 358-363.

Renandya, W. A. And Richards, J. . (2002) Methodology In Language Teaching. New York: Cambridge University.

Sugiyono (2011) Metode Penelitian Kuantitatif, Kualitatif Dan Rnd. Bandung: Alfabeta. Suyanto, K. K. . (2008) English For Young Learners. Jakarta: Bumi Aksara. 